Original Article

\title{
SCREENING OF ENDOPHYTIC BACTERIA PRODUCING ANTIFUNGAL ISOLATED FROM INDONESIA MEDICINAL PLANT, JAVA GINSENG (TALINUM TRIANGULARE) (JACQ.) WILLD
}

\author{
ALIMUDDIN ALI ${ }^{a^{*}}$, HERLINA RANTE ${ }^{b}$ \\ aLaboratory of Microbiology, Department of Biology, Faculty of Mathematic and Natural Sciences, Universitas Negeri Makassar, South \\ Sulawesi, Indonesia 90233, bLaboratory of Microbiology, Faculty of Pharmacy, Hasanuddin University, South Sulawesi, Indonesia 90245 \\ Email: muddin_69@unm.ac.id
}

Received: 18 Mar 2018 Revised and Accepted: 15 May 2018

ABSTRACT

Objective: The objective of this research was to isolate and characterize endophytic bacteria from Talinum triangulare having antifungal activity.

Methods: The endophytic bacteria were isolated from roots tissue of Talinum triangulare by surface sterilization method. The isolates were cultured in Trypticase Soybean agar and antagonist activities were evaluated by dual culture assay against Fusarium oxysporum, Trichoderma reesei and Candida albicans. For metabolite antifungal activities, bacterial isolates were grown for $4 \mathrm{~d}$ in TS broth at $35{ }^{\circ} \mathrm{C}$ under shaking condition. The antifungal activities of the supernatant extract were determined by using the disk agar diffusion. Polyketide synthase (PKS I) and NRPS genes fragments of all isolates were amplified.

Results: The result reveals that 4 of 23 endophytic bacterial isolates demonstrated great antifungal potentiality against many tested fungi. Polyketide synthase (PKS I) and NRPS genes amplification were showed 10 and 4 of endophytic isolates detected harboring PKS type I and NRPS genes, respectively. In general, high frequencies of positive PCR amplification were obtained for PKS I (43.47\%). Phylogenetic analyses based on the 16S rRNA gene sequence, morphological, physiological and biochemical showed that the isolates were identified as a member of genus Bacillus and Brevibacillus.

Conclusion: These results indicated that the endophytic bacteria from java ginseng could be used as an alternative source of antifungal agents.

Keywords: Endophytic bacteria, Antifungal, Talinum triangulare, PKS I, NRPS, 16S rRNA

(c) 2018 The Authors. Published by Innovare Academic Sciences Pvt Ltd. This is an open access article under the CC BY license (http://creativecommons.org/licenses/by/4.0/) DOI: http://dx.doi.org/10.22159/ijpps.2018v10i6.26037

\section{INTRODUCTION}

Endophytic microorganisms are defined as those microorganism that show endosymbiosis relationship with their host plants. These can be isolated from tissues or plant organ. Plants and microorganisms shows a complex interaction in the environment through produce a natural compounds for survival beneficial of them. Because the role of these compounds is high biological activity, so it can be searched for drug discovery [1]. These interaction occur by the environmental recognition followed by transference of molecular. Therefore, plant find a benefit such as improve tolerance to various environmental stress, plant growth stimulation or prevent of the disease against pathogens [2-4]. Many reported in literature that diseases caused by fungi, bacteria, viruses and even damage caused by insects or nematodes can be prevented by inoculation of endophytic bacteria into plant tissue. [5-8].

Association of microorganisms and plants has been reported, among others: the group of Actinobacteria such as Saccharopolyspora endophytica sp. nov isolated from Maytenus austroyunnanensis roots plant, a traditional medicinal plant in China [9]. Endophytic bacteria confer benefit extensively to plant such as enhanced resistence to various pathogen $[10,11]$. Actinobacteria isolates from plants like grapes (Monstera sp.) which produce coronamycin and show inhibitory activity against fungi Pythiaceous. This compound is also known to inhibit the growth of the human fungal pathogen, Cryptococcus neoformans [12].

The study of endophytic microorganisms commonly reported on plants from temperate climate region. Many of researchers were began to focused on the plant tropical regions $[13,14]$. The research of tropical endophytic microorganisms was trigged by the important role of microorganisms endophytic against of global diversity. Moreover, the dynamics of plant communities as a source of new bioactive compounds and biological control agent were used for tropical agroforestry $[15,16]$.
Talinum triangulare (Jacq.)(Willd.), commonly found in Indonesia and is widely distributed throughout the tropical and subtropical regions of Southeast Asia. In Indonesia, it is known as "Java Ginseng". Traditionally, particularly of South Sulawesi people has been used in herbal formulations for treatment of fatique and backache. Moreover, there are no previous literature reports on isolation endophytic bacteria anti fungi from these plants.

Isolation of antifungal compounds from various plant sources, especially endophytic plants have difficulty both chemical and physical. A new technique to find a novel compound has been improved to obtain the compounds in a short time. Molecular approaches were used to discover the novelty of compounds by exploration of genes that coding formation of substance metabolites [17]. One of the substance was attracting attention is PKS (polyketide synthases). It is a multifunctional enzyme which responsibility for polyketides biosynthesis. Polyketides is a group of important secondary metabolites that produced by microorganisms. These metabolites has various structure and many biological active substances such as antibacterial, antifungal, anticancer and immunosuppressant $[18,19]$. The present study involved the isolation of endophytic bacteria from the tissue of healthy plants (Talinum sp.), detection of $p k s$ and nrps genes and evaluation of the antifungal activity of their secondary metabolites.

\section{MATERIALS AND METHODS}

\section{Collection of the plant material}

Healthy plants of T. triangulare was collected from Sidrap district, South Sulawesi provinces of Indonesia at five different location (fig. 1). The distances between the selected site sampling is $10 \mathrm{~km}$. Roots were collected by digging the soil adjacent of the main stem. The roots sample were cutted about $3-4 \mathrm{~cm}$ in length and collected in zip lock plastic. All sample were brought into the laboratory and isolation were done within in $48 \mathrm{~h}$. A herbarium specimen as been 
preserved in Laboratory of Botany, Department of Biology, Universitas Negeri Makassar, Indonesia. The authentication of the sample was done by Dr. St. Fatma Hiola (voucher specimen no LB/FMIPA/UNM/CN001-2015).

\section{Isolation of endophytic bacteria}

Plant roots were washed with running tap water to remove soils or particles that attached on the roots surface and cut into small pieces of $c a .0 .3 \times 2 \mathrm{~cm}^{2}$. They were then surface-sterilized in $70 \%$ ethanol for $1 \mathrm{~min}$ and air-dried in a laminar flow chamber. These pieces roots tissues were rinsed in $0.1 \%$ Tween 20 for $30 \mathrm{~s}$, then in $0.5 \%$ sodium hypochlorite for 2 min. Finally, pieces roots were washed in sterilized distilled water for $5 \mathrm{~min}$, then dried using sterile filter paper. Roots were cut into small pieces by scalpel, then subsequently crushed with a pestle in a mortar under sterile conditions [20, 21]. Approximately $0.1 \mathrm{ml}$ of suspension were spread on the surface of TSA media plate amended by nystatin $100 \mu \mathrm{g} / \mathrm{ml}$ of medium. The plate was incubated at $35{ }^{\circ} \mathrm{C}$ for $7 \mathrm{~d}$ until showing growth of colonies. Colonies on the medium were independently transferred onto freshly prepared TSA medium plate until a single colony isolates showed purity. The pure isolates were streaking on Nutrient agar slant as isolates stock for further studies.

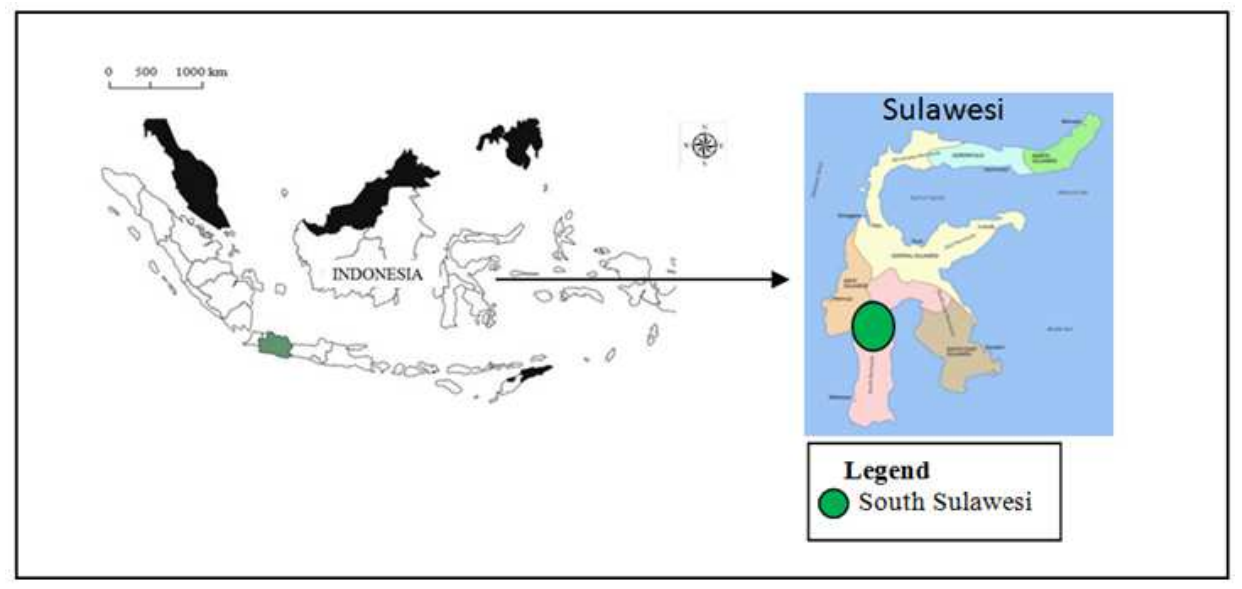

Fig. 1: Map showing the location of the sampling sites. Sidrap district, South Sulawesi, Indonesia

\section{Characterization of isolate}

The potent selected isolates were characterized by morphological and biochemical methods. Morphology of the isolate colonies was determined in TSA media. Morphological methods consist of macroscopic and microscopic methods. The micro-morphological characteristics were studied by light microscopy on the $3 \mathrm{~d}$ cultures in TSA media. The biochemical characterization was done by casein and starch hydrolysis, and growth temperature range. The observed structure was compared with Bergey's Manual of Determinative Bacteriology [22].

\section{Detection of antifungal activity}

\section{Test organism}

Three test fungi, viz., Fusarium oxysporum KFCC 11363P, Trichoderma reesei NBRC 31329 and Candida albicans ATCC 90026 were used for antagonist activities. These test organisms were procured from the Research Center for Biotechnology, Gadjah Mada of University, Yogyakarta, Indonesia.

\section{Antifungal activity}

Detection of antifungal activity of isolates was evaluated by using dual culture assay method against the test fungi [23]. The isolates were streaked on the edge of the TSA plate, while the test fungi were inoculated at the centre of the plate on the same media. The plate was incubated for $7 \mathrm{~d}$ at $35^{\circ} \mathrm{C}$. Endophytic bacteria isolates were showed the growth inhibition against test fungi (clear zone around the endophytic bacterial isolates) considered as isolates producing antifungal.

\section{Fermentation and extraction of metabolites}

The extraction of the antifungal metabolite was conducted to ensure that the mechanism of inhibition is not due to nutrient competition. The pure culture of endophytic isolates was grown on $100 \mathrm{ml}$ of TS broth media in Erlenmeyer flask $500 \mathrm{ml}$ and fermented for $4 \mathrm{~d}$ at 35 ${ }^{\circ} \mathrm{C}$ in a shaker incubator. After the fermentation liquid was centrifuged for $15 \mathrm{~min}$ at $7500 \mathrm{rpm}$ and the supernatant was used to evaluate antifungal activity. Subsequently, the supernatant was extracted by ethyl acetate, chloroform and $n$-hexane solvent 1 : 1 $\mathrm{v} / \mathrm{v}$ ) and the extract was subjected to rotary evaporatory at $40^{\circ} \mathrm{C}$ to remove the excess of solvent. The extract was obtained used to antifungal inhibition by paper disc diffusion method after dissolved in $10 \%$ dimethyl sulfoxide (DMSO).

\section{Determination of MIC value}

The MIC (Minimun Inhibitory Concentration) value of extracts was evaluated using Candida albicans ATCC 90026 as a test fungi. The serial two-fold dilutions of the crude extracts were made in a concentration which ranged from $0.5 \mu \mathrm{g} / \mathrm{ml}$ to $256 \mu \mathrm{g} / \mathrm{ml}$. Microbial suspension $(50 \mu \mathrm{l})$ containing $10^{6} \mathrm{cfu} / \mathrm{ml}$ of $C$. albicans was poured into each well of the 96-well microplate. One well-contained $50 \mu \mathrm{l}$ of microbial suspension which was added a $50 \mu \mathrm{l}$ of $1 \%$ DMSO and Ketoconazole were used as a negative and positive control, respectively. The plates were incubated with agitation at $30^{\circ} \mathrm{C}$ for $48 \mathrm{~h}$. The MIC was defined as the lowest concentration of extract that inhibited the growth of test fungi after streaked onto Sabouraud Dextrose agar and incubated under appropriate conditions.

\section{Amplification of PKS type I, NRPS and 16S rRNA genes}

The DNA genome of selected isolates were isolated from cells grown in TS broth according to the method as described by [24]. Isolates were grown on TS broth medium for $24 \mathrm{~h}$ at $35{ }^{\circ} \mathrm{C}$ in an incubator shaker. Biomass cell were harvested by centrifuging at $5000 \mathrm{rpm}$ for 20 min. Pellet was washed twice with TE pH 8.0 (Tris EDTA buffer). Subsequently the pellet was used for DNA extraction by following the steps as follows: cells were lysed with $800 \mu \mathrm{l}$ of lysis solution (100 mmol/l Tris-HCl, pH7; 20 mmol/l EDTA; $250 \mathrm{mmol} / \mathrm{l} \mathrm{NaCl} ; 2 \%$ $\mathrm{m} / \mathrm{v}$ SDS; $1 \mathrm{mg} / \mathrm{ml}$ lysozime), and added $5 \mathrm{ml}$ of $50 \mathrm{mg} / \mathrm{ml} \mathrm{RNAse}$ solution. The suspension was incubated at $37^{\circ} \mathrm{C}$ for $60 \mathrm{~min}$. After was added of $10 \mu \mathrm{l}$ of proteinase $\mathrm{K}(50 \mathrm{mg} / \mathrm{ml})$ and lysis solution, suspension was incubated at $65^{\circ} \mathrm{C}$ for $30 \mathrm{~min}$. Lysate was extracted with an equal volume of phenol and centrifuged at $13,000 \mathrm{rpm}$ for $10 \mathrm{~min}$. Supernatant were re-extracted with phenol (50\%-50\% v/v), then with chloroform $(50 \%-50 \% \mathrm{v} / \mathrm{v})$. DNA was obtained from the aqueous phase by the addition of $\mathrm{NaCl}(150 \mathrm{mmol} / \mathrm{l}$, final concentration) and 2 times volumes of cold ethanol $95 \% \mathrm{v} / \mathrm{v}$ before centrifugation. Precipitates of DNA was cleaned with $50 \mu \mathrm{l}$ of $70 \%$ ethanol and resuspended with TE buffer $(10 \mathrm{mmol} / \mathrm{l}$ Tris- $\mathrm{HCl} \mathrm{pH}$ 
7,4; $1 \mathrm{mmol} / \mathrm{l}$ EDTA, pH 8). The purity of DNA was evaluated using spectrophotometry and stored at $-20^{\circ} \mathrm{C}$ for further studies

Reaction of gene amplification were performed in a final volume of $50 \mu \mathrm{l}$ containing $1 \mu \mathrm{l}$ of $25 \mathrm{pmol}$ each degenerate primer for PKs genes ACP sense [forward: K1F 5'-TSAAGTCSAACATCGGBCA-3'), KS antisense (reverse: M6R 5'-CGCAGGTTSCSGTACCAGTA-3'). Nonribosomal peptide synthetase (NRPS) adenylation domain was amplified with the degenerate primer: Sense A3F (5'GCSTACSYSATSTACACSTCSGG-3'),A7R(5-'SASGTCVCCSGTSCGGTAS$\left.3^{\prime}\right)$. The pylogenic analysis of $16 \mathrm{~S}$ rRNA isolate was amplified with [forward: 27F (5'AGAGTTTGATC CTGGCTCAG-3'), (reverse: 1492R

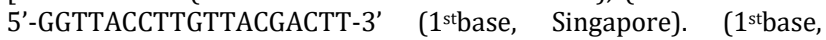
Singapore)], $1 \mu \mathrm{l}$ of extracted DNA and PCR master mix (GoTaq $囚$ Green). Amplification of $16 \mathrm{~S}$ rRNA gene was carried out by polymerase chain reaction using a thermocycler (Bio-Rad, USA). The thermocycling condition profile consisted of an initial denaturation at $95{ }^{\circ} \mathrm{C}$ for $3 \mathrm{~min}, 30$ amplification cycles of $94{ }^{\circ} \mathrm{C}$ for $2 \mathrm{~min}$ (denaturation), $56{ }^{\circ} \mathrm{C}$ for $1 \mathrm{~min}$ (annealling), and $72{ }^{\circ} \mathrm{C}$ for $2 \mathrm{~min}$ (extension) and final polymerization at $72{ }^{\circ} \mathrm{C}$ for $10 \mathrm{~min}$. The amplification products were visualized by electrophoresis in $1 \%$ $(\mathrm{w} / \mathrm{v})$ agarose gels stained with ethidium bromide.

\section{Phylogenetic analysis of $16 S$ rRNA gene}

The ribosomal RNA gene sequences of the selected isolates were aligned compared with the related taxa sequences of 16S rRNA gene from GenBank database. Multiple alignments were obtained manually using the Clustal X 1.8 program [25]. A phylogenic tree was constructed by using the neighbour-joining method using the Phylip version 3.5 program [26] with bootstrap values based on 1000 replications [27]. The similarities matrix and nucleotides different of ribosomal gen inter-species from database were analysed by Phydit version 3.0 program (The Phylogenetic Moleculaer Sequences Editor) [28].

\section{RESULTS AND DISCUSSION}

\section{Characteristic of isolates}

A total of 23 endophytic bacteria were isolated from plant internal root tissues. The isolates were cultured on media and identified based on different morphological characters and expressed as endophytic isolates (table 1). All of the isolates exhibited nonfilamentous bacteria colony, actinomycetes groups. The endophyte colonies were carried out purification to obtain a purified isolate. In general, the colonies colour were found milky white to light yellow, cells are rod shape. The colour colony of isolates were exhibited similar on morphological characters, but it can be distinguished on the biochemical profiles. The isolate was grown well at $20^{\circ} \mathrm{C}$ to $45^{\circ} \mathrm{C}$ but does not grow at 4 or $55^{\circ} \mathrm{C}$.

The last rinsing water of isolation process was grown on the same media for checking the presence of non-endophytic bacteria uneliminated on the surface of the root tissues. The colony were grown in last soaking and exhibit similar with plating media used as a control for eliminate the non-target colony. There are 1 to 2 colonies are grow on media plate control varying shape and colony colour.

Table 1: Morphological and physiological characteristic of endophytic bacteria

\begin{tabular}{lllllll}
\hline Isolate ID & \multicolumn{7}{l}{ Physiological characteristics } & & & Cells shape \\
\cline { 2 - 5 } & Gram staining & ${ }^{a}$ Spora-forming & ${ }^{b}$ Casein hydrolysis & Starch hydrolysis & Growth temperature range ( ${ }^{\circ}$ C) \\
\hline GJ2.1 & positive & + & + & - & $20-50$ & Rod shape \\
GJ2.2 & positive & - & - & + & $20-50$ & $20-50$ \\
GJ2.3 & positive & + & + & - & $20-50$ & Coccus \\
GJ2.6 & positive & - & + & + & $20-45$ & Rod shape \\
GJ2.7 & negative & - & + & + & $15-45$ & Coccus \\
GJ2.9 & negative & - & + & - & $20-50$ & Rod shape \\
GJ3.1 & positive & + & + & - & $20-45$ & Coccus \\
GJ3.4 & negative & - & - & + & $20-45$ & Curved Rod \\
GJ3.6 & positive & - & - & + & $20-50$ & Short rods \\
GJ3.7 & positive & + & + & - & $15-45$ & Coccus \\
GJ4.1 & negative & - & + & - & $20-50$ & Rod shape \\
GJ4.2 & negative & - & + & + & $15-45$ & Rod shape \\
GJ4.3 & positive & + & + & - & $20-45$ & Short rods \\
GJ4.5 & negative & - & + & + & $14-45$ & Rod shape \\
GJ4.6 & negative & - & - & - & $20-45$ & Rod shape \\
GJ4.7 & positive & - & - & - & $20-50$ & Rod shape \\
GJ4.9 & negative & - & + & - & $15-45$ & Coccus \\
GJ5.1 & positive & - & + & + & $20-50$ & Short rods \\
GJ5.3 & positive & + & - & + & $20-50$ & Coccus \\
GJ5.4 & negative & - & - & - & Rod shape \\
GJ5.6 & positive & - & - & - & Short rod \\
GJ5.7 & positive & + & + & -45 & Short rods \\
GJ5.9 & positive & + & - & & Rod chain \\
\hline
\end{tabular}

$a+$, present; -, absent $b+$, active; -, no activity

\section{The antifungi activity of isolate}

Four isolates of endophytic bacteria were designated as GJ2.1, GJ3.1, GJ4.3 and GJ5.3 show growth inhibition against test fungi by the formation of a clear zone around the block agar (a zone is not covered by test fungi colony) (fig. 2). It is suggested that the isolate producing antifungal substances.

However, the inhibitory mechanisms of isolate on microorganism not always caused by antifungal compounds produced by bacterial isolate but may also be due to other mechanisms.

Therefore, to determine of inhibition mechanism, the fermentation broth were extracted using non-polar solvent. The results of diffusion agar showed the antifungal activity against test fungi. Three of solvent with different level polarity showed different activities against test fungi. The ethylacetate extract was showed activities while weak to no detect by chloroform and n-hexane extract. Subsequently, the MIC value of each ethylacetate extract were various values (table 2).

\section{Amplification of PKS I and NRPS gene}

These isolates were carried out detection of PKS type I for the screened presence of polyketide biosynthesis genes. All isolates are detected of PCR amplification for PKS-I dan NRPS was revealed at $1400 \mathrm{bp}$ bands and $700 \mathrm{bp}$, respectively bp. These results indicated that the endophytic bacteria isolates were 
positive of polyketide biosynthesis system. Four of 23 isolates were able to inhibit growth two species of test fungi based on halo zone forming arround the bacterial isolates colony. Five of isolates were inhibit against tested fungal detected of PKS amplicons, whereas three isolates of NRPS amplicons were detected but two isolates, (GJ2.3 and GJ3.1) show antifungal produce (table 3 ).

\section{Phylogeni of endophytic bacteria isolates}

Preliminary characterization of selected isolates by profile matching approach as a key character for a basic reference with related genera. The isolates are showed high similarities with Bacillus sp. genus character e. g: Gram-positive, rod-shaped and endospores-forming. These character was enough to revealed that the isolates are including in the group of Bacillus.

Nevertheless, it is necessary to evaluate determination of related species with other species based on database analysis of ribosomal genes. Analysis of 16S rRNA gene sequences of the isolates was used to perform phylogenetic construction by compare of the $16 \mathrm{~S}$ rRNA gene sequences, all isolates are members of belong to the type species of Bacillus (GJ2.1, GJ5.3, GJ4.3) or Brevibacillus (GJ2.3 and GJ3.1) as shown in fig. 3.

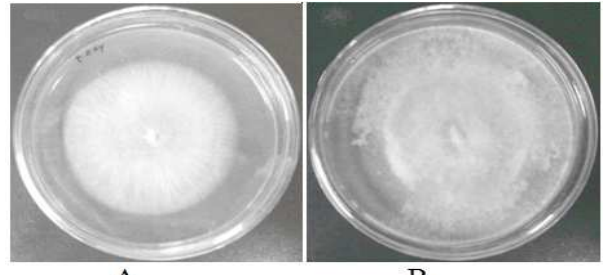

A B

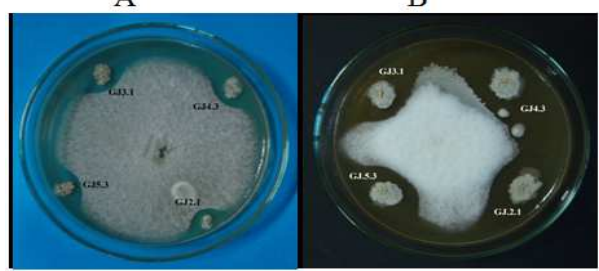

$\mathrm{C}$

$\mathrm{D}$

Fig. 2: In vitro inhibition activity of selected endophytic bacteria isolate against test fungi (A) Control plate of Fusarium oxysporum KFCC 11363P, (B) Control plate of Trichoderma reesei NBRC 31329 (C) Fusarium oxysporum, (D) Trichoderma reesei

Table 2: Antifungal activities of endophytic bacterial and MIC value of extract crude

\begin{tabular}{lllll}
\hline \multirow{2}{*}{ Isolate ID } & \multicolumn{3}{l}{ Antifungal activities of extract crude ${ }^{a}$} & \multicolumn{2}{c}{ MIC $(\boldsymbol{\mu g} / \mathbf{m l})$ of ethyl acetate extract against $\boldsymbol{C}$. albicans ATCC 90026 } \\
\cline { 2 - 4 } & Ethyl acetate & Chloroform & $\mathbf{n}$-hexane & \\
\hline GJ2.1 & ++ & + & - & 128.04 \\
GJ2.3 & +++ & ++ & - & 57.32 \\
GJ5.3 & ++ & - & - & $>256.11$ \\
GJ3.1 & +++ & + & - & 64.24 \\
GJ4.3 & ++ & - & - & $>256.67$ \\
Ketoconazole & & & & 0.50 \\
\hline
\end{tabular}

aEstimated by measuring the diameter of the clear zone of growth inhibition, each isolate was tested using 3 replications,+++, $\geq 15 \mathrm{~mm} ;++, \geq 10-15$ $\mathrm{mm} ;+, \geq 5-10 \mathrm{~mm} ;-,<5 \mathrm{~mm}$ (no antifungal activity).

Table 3: In vitro anti microbes activity of all isolates and metabolite biosynthetic genes

\begin{tabular}{|c|c|c|c|c|c|c|}
\hline \multirow[t]{2}{*}{ S. No. } & \multirow[t]{2}{*}{ Isolate ID } & \multicolumn{3}{|c|}{$\begin{array}{l}{ }^{a} \text { In vitro anti microbes activity } \\
\text { (dual culture assay) }\end{array}$} & \multicolumn{2}{|c|}{$b$ Metabolite biosynthetic genes } \\
\hline & & $\begin{array}{l}\text { F. oxysporum } \\
\text { KFCC 11363P }\end{array}$ & $\begin{array}{l}\text { T. reesei } \\
\text { NBRC } 31329\end{array}$ & $\begin{array}{l}\text { C. albicans } \\
\text { ATCC } 90026\end{array}$ & PKS & NRPS \\
\hline 1 & GJ2.1 & Active & Active & Active & + & - \\
\hline 2 & GJ2.2 & ND & ND & ND & - & - \\
\hline 3 & GJ2.3 & Active & Active & Active & + & + \\
\hline 4 & GJ2.6 & ND & ND & ND & - & + \\
\hline 5 & GJ2.7 & ND & ND & ND & + & - \\
\hline 6 & GJ2.9 & ND & ND & ND & - & - \\
\hline 7 & GJ3.1 & Active & Active & Active & + & + \\
\hline 8 & GJ3.4 & ND & ND & ND & + & - \\
\hline 9 & GJ3.6 & ND & ND & ND & - & - \\
\hline 10 & GJ3.7 & ND & ND & ND & + & - \\
\hline 11 & GJ4.1 & ND & ND & ND & - & - \\
\hline 12 & GJ4.2 & ND & ND & ND & - & - \\
\hline 13 & GJ4.3 & Active & Active & Active & + & - \\
\hline 14 & GJ4.5 & ND & ND & ND & - & - \\
\hline 15 & GJ4.6 & ND & ND & ND & + & - \\
\hline 16 & GJ4.7 & ND & ND & ND & - & - \\
\hline 17 & GJ4.9 & ND & ND & ND & - & + \\
\hline 18 & GJ5.1 & ND & ND & ND & - & - \\
\hline 19 & GJ5.3 & Active & Active & Active & + & - \\
\hline 20 & GJ5.4 & ND & ND & ND & - & - \\
\hline 21 & GJ5.6 & ND & ND & ND & - & - \\
\hline 22 & GJ5.7 & ND & ND & ND & - & - \\
\hline 23 & GJ5.9 & ND & ND & ND & + & - \\
\hline
\end{tabular}

${ }^{a} \mathrm{ND}=$ not detected ${ }^{b}+$, present; - , absent 


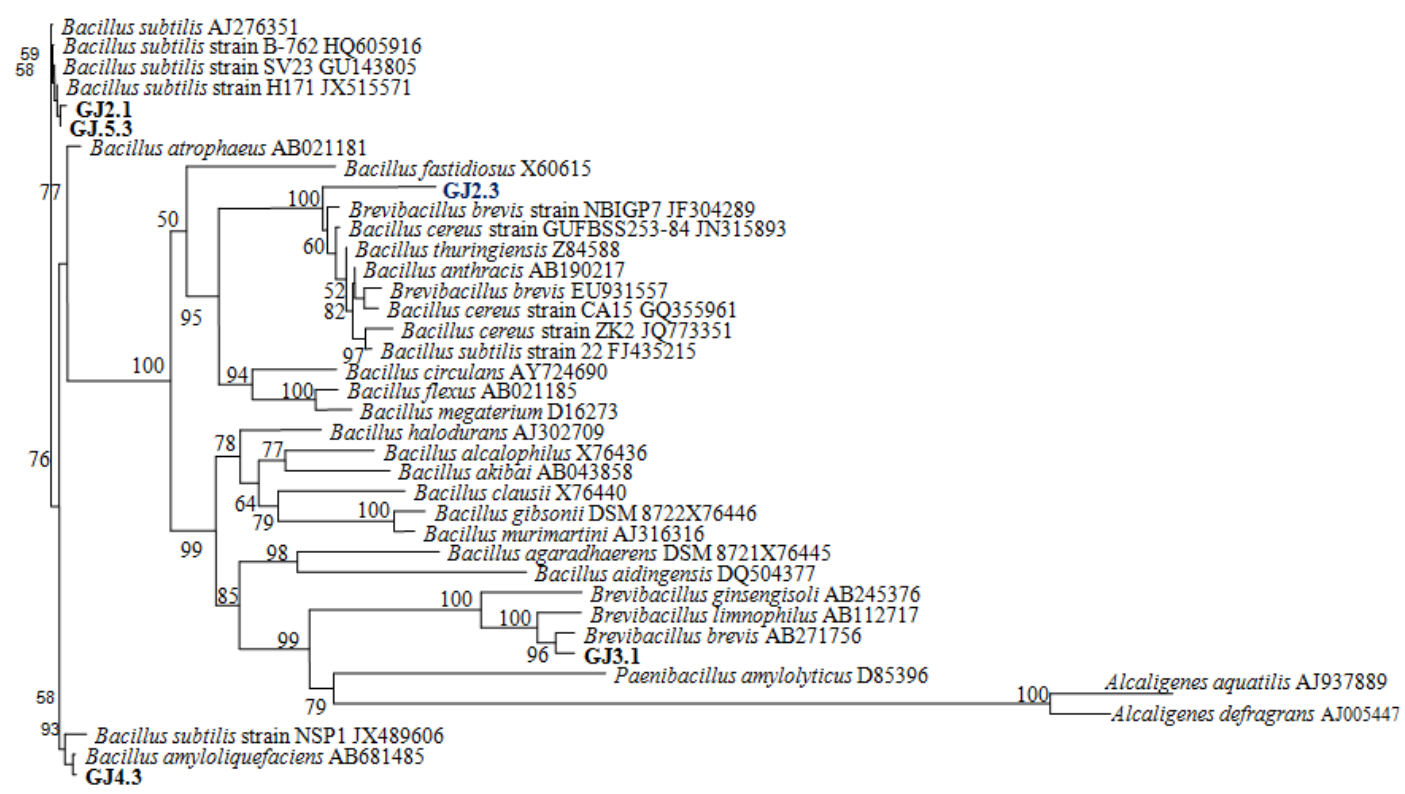

Fig. 3: Neighbour-joining phylogenetic tree inferred from $16 \mathrm{~S}$ rRNA gene sequences. The phylogenetic tree shows the phylogenetic relationship of endophytic bacteria isolates with related genera. Bootstrap values are expressed as percentages of 1000 replications. Bootstrap values, $\mathbf{2 5 0} \%$ are shown at branch points. Score bar represents 1 nucleotide substitution per 100 nucleotides

\section{DISCUSSION}

All of the plant compartments including seeds were obtained by endophytic bacteria. These bacteria generally colonize and forming a community in intracellular spaces both monocotyledonous and dicotyledonous plants [29]. Endophytic bacteria isolates were taken from free-disease Talinum sp. of several site sampling in South Sulawesi, Indonesia yielded 23 isolates. In this study, we explored the plant roots as an alternative source for screening of endophytic microorganisms. Our results of the research have shown that roots of java ginseng inhabited of diverse of bacteria. This work and other reports support that plant roots are the habitat of microorganisms. It has an important role with regard to plant health through nutrient assimilation or the in situ secretion many secondary metabolites that affected of plant growth [30,31].

All isolates were obtained considered as endophytic bacteria because they had the different characteristic of colonies growing on control media plates. The effectiveness of surface sterilization was carried out to eliminate the epiphytic microorganisms were enough good. The colonies were growth on the control media plate from final rinse of the specimen when sterilization was different of colony characters between colony endophytic than non-endophytic. Based on the criteria, colonies grew on plate expressed as endophyte bacteria. The key of success to isolate endophytic microorganisms are surface sterilization guarantee of plant specimen or organs [32].

The existence of endophytic bacteria was obtained from the root of java ginseng suggests that the plant is one of a good habitat for endophytic bacteria. Some microorganisms such as bacteria, fungi and Actinobacteria have been isolated from ginseng rhizosphere [33]. Endophytic fungi were isolated from different parts of medicinal plant Justicia wynaadensis Heyne, was shown antibacterial and antioxidative [34]. The presence of abundant microorganisms in around of the plant roots area by specific mechanisms are moving entrance into the root tissue to form an association with host plants. These mechanisms are influenced by many biological and environmental factors such as cultivar of the plant, age, type of tissue and sampling time $[35,36]$.

Endophytic microorganisms on plant tissues organ as an alternative source of microorganism's exploration become an interesting object. Various methods have been developed to identify a potential of isolates producing bioactive substances such as detection of genes which responsible for biosynthesis system of compounds. Many primers have been reported used to amplify of region encoding of ketosintase module, acyltransferase and adenilase [24]. A result of gene amplification was showed that five of endophytic isolates detected harboring PKS type I genes. In general, high frequencies of positive PCR amplification were obtained for PKS I (43.47\%). The high detection level of PKS-I biosynthetic genes observed in the isolates confirm the diversity of distribution of these sequences in this genera on java ginseng plant. These gene plays an important role to produce secondary metabolites, especially of polyketide compounds structures. Therefore, although was not the known structure of bioactive compounds produced of endophytic isolates, it could be stated that these isolates synthesized polyketide compounds. Meanwhile, the isolat CJ3.1 (closely related to Brevibacillus brevis) was antifungal production show harboring NRPS gene (17.39\%). Although the substances were not determined of chemical structure, however, the study was reported revealed that Brevibacillus brevis was coding tyrocidine synthase 2 tycB and gramicidin S synthetase [37].

Results of these studies indicate that endophytic bacteria which producing bioactive metabolites established the benefits interaction with the host [2]. Microorganisms often act as an antagonistic community to protect of the host against pathogenic fungi. Other competitions may be also caused by essential element competition process such as the formation of sideropore to binding $\mathrm{Fe}$ ions (chelating). Defisiention of the essential element caused a metabolism and reproduction process was disturbed [38].

Our results showed that the ethyl acetate extract of selected bacteria was detected inhibit the growth of fungi test while other extract solvent had no activities. A similar finding was observed in the report of antimicrobial activity of endophytic microbes isolated from medicinal plant Cardiospermum halicacabum [39]. The successively of bioactive substances isolation depends upon the type of solvent used in extraction procedure [40]. Moreover, endophytic microbia have been known to produce antifungal substances extractable with ethyl acetate. Therefore, it was suggested that inhibition factor against fungal test growth by isolates was not caused by nutrients competition, but antifungal compounds produced by the endophytic bacterial isolates.

Molecular approaches of isolation and characterization of endophytic bacteria were reported. Microorganisms colonizing in the roots, stems and tubers tissues of plant different varieties have been analysed by $16 \mathrm{~S}$ rRNA gene. The diversity of bacteria colonizing agronomic crops such as Cellulomonas, Clavibacter, 
Curtobacterium, Pseudomonas and Microbacterium had reported [35].

Phylogeni analysis of $16 \mathrm{~S}$ rRNA gene sequences showed that isolates were clustering into Bacillus and Brevibacillus genera. Our results concluded that the selected endophytic bacteria are a member of the Bacillus genus and closely related to Bacillus and Brevib acillus brevis. B. brevis was first described in 1990 [33] and reclassification as a new species of Brevibacillus brevis and a new genus: Brevibacillus. Subsequently, there are many isolates was identified as a new species such as Brevibacillus invocatus [41] and Brevibacillus limnophilus [42]. Based on of the phylogenetic distance from recognized Brevibacillus species, and relatively low $16 \mathrm{~S}$ rRNA gene sequence similarities ( $<97 \%$; see fig. 3 ), it is apparently that GJ3.1 and GJ2.3 isolates could be determined by the novelty species of the genus Brevibacillus. However, limitation of presented data makes it difficult to represents of isolates as a novel species.

\section{CONCLUSION}

Java ginseng plant is one of the alternative sources of endophytic bacterial producing antifungal. The endophytic bacterial isolate that was described in this study had Potential as produce antifungal agent because of promosing due to their ability to produce endospore. The selected isolate was detected harboring a PKS I gene and NRPS for screened a polyketide biosynthesis peptide non ribosome system, respectively. Analysis of 16S rRNA gene showed that the isolate producing anti fungi closely related to Bacillus and Brevibacillus genera.

\section{ACKNOWLEDGEMENT}

We would like to acknowledge the Ministry of Research and Technology, Higher Education of Indonesia for the financial support.

\section{AUTHORS CONTRIBUTIONS}

All the author have contributed equally

\section{CONFLICTS OF INTERESTS}

All authors declare no conflict of interest

\section{REFERENCES}

1. Pupo MT, Guimarães DO, Furtado NAJC, Borges WS. Microbial natural products: a promising source of bioactive compounds. In: Modern Biotechnology in Medicinal Chemistry and Industry. Taft, C. A. Ed. Kerala, India; Research Signpost; 2006. p. 51-78.

2. Hasegawa S, Meguro A, Shimizu M, Nishimura T, Kunoh H. Endophytic actinomycetes and their interactions with plants. Actinomycetol 2006;20:72-81.

3. Sun L, Qiu F, Zhang X, Dai X, Dong X, Song W. Endophytic bacterial diversity in rice (Oryza sativa L.) roots estimated by 16S rDNA sequence analysis. Microb Ecol 2008;55:415-24.

4. Braga RM, Dourado MN, Araũjo WL. Microbial interactions: ecology in a molecular perspective. Braz J Microbiol 2016;47S:86-98.

5. Kerry BR. Rhizosphere interactions and the exploitation of microbial agents for the biological control of plant-parasitic nematodes. Annu Rev Phytopathol 2000;38:423-41.

6. Sturz AV, Christie BR, Nowak J. Bacterial endophytes: potential role in developing sustainable systems of crop production. Crit Rev Plant Sci 2000;19:1-30.

7. Ping L, Boland W. Signals from the underground: bacterial volatiles promote growth in Arabidopsis. Trends Plant Sci 2004; 9:263-66.

8. Berg G, Hallmann J. Control of plant pathogenic fungi with bacterial endophytes. Microbial Root Endophytes (Schulz BJE, Boyle CJC and Sieber TN, eds), Springer-Verlag, Berlin; 2006. p. 53-69.

9. Qin $\mathrm{S}$, Wang $\mathrm{HB}$, Chen $\mathrm{HH}$, Zhang $\mathrm{YQ}$, Jiang $\mathrm{CL}, \mathrm{Xu} \mathrm{LH}$, et al. Glycomyces endophyticus sp. nov., an endophytic actinomycete isolated from the root of Carex baccans Nees. Int J Syst Evol Microbiol 2008;58:2525-8.

10. Clay K, Schardl CL. Evolutionary origins and ecological consequences of endophyte symbiosis with grasses; Am Midl Nat 2002;160:99-127.
11. Arnold AE, Maynard Z, Gilbert GS. Fungal endophytes in dicotyledonous neotropical trees: patterns of abundance and diversity. Mycol Res 2001;105:1502-7.

12. Ezra D, Castillo UF, Strobel GA, Hess WM, Porter H, Jensen JB, et al. Coronamycins, peptide antibiotics produced by a verticillate Streptomyces sp. (MSU-2110) endophytic on Monstera sp. Microbiology 2004;150:785-93.

13. Rodrigues KF, Petrini O. Biodiversity of endophytic fungi in tropical regions. In: Hyde KD. Ed. Biodiversity of Tropical Microfungi. Hong Kong, University of Hong Kong Press; 1997. p. 57-69.

14. Gasong BT, Tjandrawinata RR. Production of secondary metabolite E2.2 from Phaleria macrocarpa endophytic fungus. Asian Pac J Trop Biomed 2016;6:881-5.

15. Hawksworth DL. The magnitude of fungal diversity: the 1.5 million species estimated revised. Mycol Res 2001;105:1422-32.

16. Arnold AE, Meffa LC, Kyollo D, Rojas EI, Maynard Z, Robbins N, et al. Fungal endophytes limit pathogen damage in a tropical tree. Proc Natl Acad Sci USA 2003;100:15649-54.

17. Mayer KM, Ford J, Macpherson GR, Padgett D, Kohlmeyer BV, Kohlmeye J, et al. Exploring the diversity of marine-derived fungal polyketide synthases. Can J Microbiol 2007;53:291-302.

18. Cane DE, Walsh CT, Khosla C. Harnessing the biosynthetic code: combinations, permutations, and mutations. Science 1998;282:63-8.

19. Menzella HG, Reid R, Carney JR, Chandran SS, Resinger SJ, Patel $\mathrm{KG}$, et al. Combinatorial polyketide biosynthesis by de novo design and rearrangement of modular polyketide synthase genes. Nat Biotechnol 2005;23:1171-6.

20. Nimnoi P, Pongsilp N, Lumyong S. Endophytic actinomycetes isolated from Aquilaria crassna Pierre ex Lec and screening of plant growth-promoters production. World J Microbiol Biotechnol 2010;26:193-203.

21. He RL, Wang GP, Liu XH, Zhang CL, Lin FC. Antagonistic bioactivity of an endophytic bacterium isolated from Epimedium brevicornu Maxim. Afr J Biotechnol 2009;8:191-5.

22. Holt JG, Krieg NR, Sneath PHA, Staley JT, Williams ST. Bergey's Manual of Determinative Bacteriology. $9^{\text {th }}$ edition. 1994.

23. Barakate $\mathrm{M}$, Ouhdouch $\mathrm{Y}$, Oufdou $\mathrm{KH}$, Beaulieu C. Characterization of rhizosperic soil Streptomyces from Moroccan habitats and their antimicrobial activities. World J Microb Biot 2002;18:49-54.

24. Ayuoso-Sacido A, Genilloud O. New PCR primers for the screening of NRPS and PKS-I systems in Actinomycetes: detection and distribution of these biosynthetic gene sequences in major taxonomic groups. Microb Ecol 2005;49:10-24.

25. Thompson JD, Gibson TJ, Plewniak F, Jeanmougin F, Higgins DG. The CLUSTAL_X windows interface: flexible strategies for multiple sequence allignment aided by quality analysis tools. Nucleic Acids Res 1997;25:4876-82.

26. Saitou N, Nei M. The neighbour-joining method: a new method for reconstructing phylogenetic trees. Mol Biol Evol 1987;4:406-25.

27. Felsenstein J. Confidence limits on phylogenies: an approach using the bootstrap. Evolution 1985;39:783-91.

28. Chun J. PHYDIT (The Phylogenetic Editor) Version 3.0. User' Manual; 1999.

29. Posada F, Vega FE. Establishment of the fungal entomopathogen Beauveria bassiana (Ascomycota: Hypocreales) as an endophyte in cocoa seedlings (Theobroma cacao). Mycologia 2005; 97:1195-200.

30. Sardi P, Saracchi M, Quaroni S, Petrolini B, Borgonovi GE, Merli S. Isolation of endophytic Streptomyces from surface-sterilized roots. Appl Environ Microbiol 1992;58:2691-3.

31. Shimizu M, Nakagawa Y, Sato Y, Furumai T, Igarashi Y, Onaka H, Yoshida R, et al. Studies on endophytic actinomycetes (I) Streptomyces sp. Isolated from Rhododendron and its antifungal activity. J Gen Plant Pathol 2000;66:360-6.

32. Hallmann J, Quadt-Hallmann A, Mahaffee WF, Kloepper JW. Bacterial endophytes in agricultural crops. Can J Microbiol 1997;43:895-914.

33. Baek SH, Im WT, Oh HW, Lee JS, Oh HM, Lee ST. Brevibacillus ginsengisoli sp. nov., a denitrifying bacterium isolated from soil of a ginseng field. Int J Syst Evol Microbiol 2006;56:2665-9. 
34. Das M, Prakash HS, Nalini MS. Antioxidative and antibacterial potentials of fungal endophytic from Justicia mynaadensis Heyne: An ethnomedicinal rainforest species of Western Ghats. Asian J Pharm Clin Res 2017;10:203-9.

35. Zinniel DK, Lambrecht P, Harris NB, Feng Z, Kuchzmarski D, Higley $\mathrm{P}$, et al. Isolation and characterization of endophytic colonizing bacteria from agronomic crops and prairie plants. Appl Environ Microbiol 2002;68:2198-208.

36. Araùjo WL, Maccheroni WJr, Aguilar-Vildoso CI, Barroso PA, Saridakis HO, Azevedo JL. Variability and interactions between endophytic bacteria and fungi isolated from leaf tissues of citrus rootstocks. Can J Microbiol 2001;47:229-36.

37. Hori K, Yamamoto Y, Minetoki T, Kurotsu T, Kanda M, Miura S, et al. Molecular cloning and nucleotide sequence of the gramicidin S synthetase 1 gene. J Biochem 1989;106:639-45.

38. Chamberlain K, Crawford DL. In vitro and in vivo antagonism of pathogenic turfgrass fungi by Streptomyces hygroscopicus strains YCED9 and WYE53. J Ind Microbiol Biotechnol 1999;23:641-6.

39. Chathurdevi G, Gowrie SU. Endophytic fungi isolated from medicinal plant-a promising source of potential bioactive metabolites. Int J Curr Pharm Res 2016;8:50-60.

40. Parekh J, Chanda S. In vitro screening of antibacterial activity of aqueous and alcoholic extracts of various Indian plant species against selected pathogens from Enterobacteriaceae. Afr J Microbiol Res 2007;1:92-9.

41. Logan NA, Forsyth L, Lebbe L, 8 other authors. Polyphasic identification of Bacillus and Brevibacillus strains from clinical, dairy and industrial specimens and proposal of Brevibacillus invocatus sp. nov. Int J Syst Evol Microbiol 2002;52:953-66.

42. Goto K, Fujita R, Kato Y, Asahara M, Yokota A. Reclassification of Brevibacillus brevis strains NCIMB 13288 and DSM 6472 (NRRL NRS-887) as Aneurinibacillus danicus sp. nov. and Brevibacillus limnophilus sp. nov. Int J Syst Evol Microbiol 2004;54:419-27. 